\title{
Reinstatement of the Patagonian moss Ulota glabella Mitt. (Bryophyta, Orthotrichaceae)
}

\author{
Ricardo GARILLETI ${ }^{1, *}$, Belén ALBERTOS ${ }^{2}$, Isabel DRAPER ${ }^{3}$, \\ Juan Antonio CALLEJA ${ }^{4} \&$ Francisco LARA ${ }^{5}$ \\ ${ }^{1,2}$ Departamento de Botánica y Geología, Facultad de Farmacia, \\ Universidad de Valencia, 46100 Burjassot, Spain. \\ 3,4,5 Departamento de Biología (Botánica), Facultad de Ciencias, \\ Universidad Autónoma de Madrid, 28049 Madrid, Spain. \\ ${ }^{3,4,5}$ Centro de Investigación en Biodiversidad y Cambio Global, 28049 Madrid, Spain. \\ *Corresponding author: belen.albertos@uv.es \\ ${ }^{1}$ Email: ricardo.garilleti@uv.es \\ ${ }^{3}$ Email: isabel.draper@uam.es \\ ${ }^{4}$ Email: juan.calleja@uam.es \\ ${ }^{5}$ Email: francisco.lara@uam.es
}

\begin{abstract}
In 1842, J.D. Hooker collected a number of mosses on Hermite Island (Cape Horn region). From one of those gatherings, Hooker 141, four species of Ulota have been described: U. luteola, $U$. fuegiana, U. glabella, and U. eremitensis. The first two species are widely accepted, whereas the identity of the latter two has been recently discussed, and the names are now synonymized under U. fuegiana, the more widely distributed species in the Tierra del Fuego archipelago. Our studies, based on recent collections of Orthotrichaceae from Patagonia, show that specimens different from those of $U$. fuegiana and agreeing with the protologues of both $U$. glabella and U. eremitensis are common in Patagonia. Comparisons with type material of all four names demonstrate that the type for U. glabella is in such bad condition that it cannot be used, and an epitype should be selected. In this paper, we comment on the whereabouts of the collection Hooker 141 and the species described from it, discuss the distinct identity of $U$. glabella and its relationship with $U$. eremitensis as well as its differentiation from other species, present a diagnostic description of $U$. glabella and, finally, select an epitype to fix the application of this name.
\end{abstract}

Keywords. Epitype, South America, Ulota eremitensis, Ulota fuegiana, Ulota macrocalycina.

Garilleti R., Albertos B., Draper I., Calleja J.A. \& Lara F. 2020. Reinstatement of the Patagonian moss Ulota glabella Mitt. (Bryophyta, Orthotrichaceae). European Journal of Taxonomy 726: 83-101. https://doi.org/10.5852/ejt.2020.726.1177

\section{Introduction}

Species identification of bryophytes often depends on the analyses of well-preserved sporophytes. This is especially true in Orthotricheae Engl. (Orthotrichaceae Arn.), where peristomes are usually essential 
for identification. On many occasions, the best and sometimes only discriminatory characteristics are the number of pieces, structure, arrangement, position when dry and ornamentation of the exostome and the endostome. However, these structures are delicate and it is not uncommon for them to deteriorate or even disappear in preserved specimens. This is observed in collections of different ages, but is especially relevant for historical material, which is often sparse and which in some cases constitutes the nomenclatural types of species in dispute. The degradation of these original specimens has sometimes been aggravated by successive studies involving their dissection. An added complication in the case of this tribe of mosses is that it is not uncommon for the original collections to be an admixture of several species that are very similar to each other (for problems in Ulota D.Mohr., see Caparrós et al. 2016; Garilleti et al. 2016, 2020; Muñoz-Puelles et al. 2017). This makes the separation of damaged specimens challenging. In many cases for which the material is currently seriously damaged, it is still possible to interpret the author's concept of a species based on three data sources: the protologue; the interpretations of other authors who evaluated in detail the original specimens when they were in good condition; and finally, the study of recent materials with which to contrast previous descriptions.

One case that combines every problem outlined above is the collection Hooker 141, which is a mixed gathering of damaged material from which several species have been described. It was collected by Joseph Dalton Hooker (1817-1911) in Hermite Island, one of the many islands in the Cape Horn region (southern South America). This collection has been studied, chronologically, by Hooker himself and Wilson (Hooker 1847), Mitten (1860), Malta (1927), and Wang \& Jia (2016). From this single gathering, four species have been described, namely Ulota luteola (Hook.f. \& Wilson) Wijk \& Margad., U. fuegiana Mitt., U. glabella Mitt., and U. eremitensis Mitt. The two first taxa are currently widely accepted but the taxonomic status of the latter two has been recently debated (Wang \& Jia 2016), and they have been subsumed under $U$. fuegiana, one of the commonest species of Ulota in the southern extreme of South America.

Our own studies, based on the interpretation of the protologues of these species, the analysis of their types, and the study of recent collections - including some from the Cape Horn region - have led us to disagree with Wang \& Jia (2016), and to recognize the existence of three distinct species, as previously delimited by Malta (1927). In this paper, we detail the different interpretations of this group of species, re-evaluate the taxonomic and nomenclatural status of Ulota glabella and $U$. eremitensis and discuss the problems arising from the poor conservation of their types.

\section{The different interpretations of the collection Hooker 141}

Hooker visited the Hermite archipelago between September $19^{\text {th }}$ and November $7^{\text {th }}, 1842$, as assistantsurgeon and botanist to the 1839-1843 Antarctic Expedition of James Clark Ross. Hooker had great expectations about the cryptogamic potential of this stage of the expedition, and on August $25^{\text {th }}$, just before leaving the Falkland Islands for Cape Horn, he wrote to his father, the botanist William Jackson Hooker: "It is, however, among the Mosses and other Cryptogams that I shall hope for novelty in the S. extremity of the American Continent... You will not wonder that after spending so long a time in the Antarctic regions, I should be most anxious to complete the Botany of this desolate part of the world, by going even to the Horn, and that any new Moss or Lichen from such latitudes appears of infinitely more value to me than a new Palm or Rafflesia would to you" (Huxley 1918). And it seems that he was not disappointed at all, as he later considered this region as "the great botanical centre of the Antarctic Ocean [...] Fuegia is richer in Mosses than any other Antarctic island: perhaps no part of the globe of equal extent yields more or finer species than Hermite Island. During the short stay of the Antarctic Expedition one hundred different kinds were found; and the naturalist, who is accustomed to collecting this tribe of plants, is well aware that a protracted search is needful in order to exhaust the Mosses of even a limited area" (Hooker, quoted in Ross 1847). Hooker collected more than 150 moss samples on Hermite Island, many of them mixed gatherings, kept in BM (Natural History Museum 2020). 
From his collection 141 from Hermite Island, Hooker described in collaboration with William Wilson (Hooker 1847) Orthotrichum luteolum Hook.f. \& Wilson ( $\equiv$ Ulota luteola), with more or less crisped leaves and a hairy calyptra. They also indicated a "var. B", with a naked calyptra, an uncommon feature for the genus Orthotrichum Hedw., and certainly rare in Ulota D.Mohr. Nevertheless, this variety was not validly published since it was not given a name. Hooker renumbered those specimens as no. $141 \mathrm{~b}$ for $O$. luteolum and $141 a$ for the var. $B$, and these were distributed to Kew (now at BM), E, NY, and PC.

Mitten (1860) studied the duplicate now held at NY and recognized four morphotypes, which led him to take the following actions: 1) rename Orthotrichum luteolum as Ulota fulvella Mitt. nom. inval.; 2) validate Hooker \& Wilson's var. $\beta$ creating U. glabella; and 3) describe two new species, $U$. eremitensis based on a morphotype with a naked calyptra and shorter capsule than U. glabella, and $U$. fuegiana based on another morphotype with a hairy calyptra. The specimens seen by Mitten (NY) were incomplete and he could only study intact peristomes in $U$. eremitensis (poorly described, but drawn on a label with the holotype of this species, NY[00737687]!), and he was unable to describe the spores of any of the species. Thus, his descriptions were mainly based on gametophytic characters (leaf margin crenulation, number of rows of differentiated basal cells, calyptra hairiness, but also the relative size of capsule and seta), lacking the very important discriminatory characters of the peristome.

Mitten (1860) supplemented the meagre description of Ulota luteola ( $\equiv$ U. fulvella) provided by Hooker and Wilson, establishing that this is the only species of the group of taxa from Hooker's collections 141a and $141 b$ with a thin band of differentiated basal marginal cells, only one to three cells wide, whereas the other species have broad bands of more than five cells. Another important character is the entire, noncrenulate leaf margins, whereas the exostome is vaguely described as formed by eight pairs of teeth split at the apices, a character that Mitten deemed to be of importance. Concerning the other species that he described, $U$. fuegiana is similar to $U$. luteola, being discriminated from the latter by its less densely hairy calyptra, the leaves with margins irregularly eroded towards the apex, and the many series of pellucid cells at the basal margins. Ulota glabella was characterized by its naked calyptrae, leaves not crisped, and the finely crenulate ("margine minute crenulato") leaf margins. Mitten did not find peristomes in the specimens he studied (NY[00737690]!, NY[00737691]!, Fig. 1A-D) and therefore nothing is said about this taxonomically important structure. Ulota eremitensis was very similar to U. glabella, since it also has naked calyptrae and finely crenulate margins, and the differences were related to the growth-form of the colonies - subpulvinate in U. glabella and in little tufts in U. eremitensis - and the seta: capsule size relationship. Mitten described the peristome of U. eremitensis with an exostome of eight pairs of teeth divided at the apices, and an endostome of eight very thin segments ("angustis capillaribus"), almost as long as the teeth. Mitten drew this peristome in the holotype of this species (NY[00737687]!). The lack of detailed peristome descriptions sometimes makes the interpretation of Mitten's taxa challenging. See Table 1 for the main differences between these four species according to Mitten (1860).

The revisionary work by Malta (1927) is of particular interest, as he assessed the full scope of the genus in South America through the study of almost all the available material at the time, including original specimens at BM and PC that Mitten could not study. Malta considered U. luteola and U. fuegiana as different, well-defined species. Regarding U. eremitensis and U. glabella, Malta did not find any differences between them except for the size and color of the capsules, so he considered them as conspecific, and synonymized U. eremitensis under U. glabella.

Malta highlighted three diagnostic characters in his description of $U$. glabella, but he used several others in the differentiation of the species. Two of them were previously noted by Mitten, namely the naked calyptrae and the finely serrate leaf margins ("Rändern fein gesägten"), which can be interpreted as the finely crenate margins of Mitten's work. The third character is a new feature not previously described, the sheathing perichaetial leaves with a broad, high base that abruptly tapers to a blunt tip. Other important 
Table 1. Main differences between Ulota luteola (Hook.f. \& Wilson) Wijk \& Margad., U. fuegiana Mitt., U. glabella Mitt., and U. eremitensis Mitt. according to Mitten (1860).

\begin{tabular}{|c|c|c|c|c|}
\hline & U. luteola & U. fuegiana & U. glabella & U. eremitensis \\
\hline Growth form & procumbent & little tufts & subpulvinate & little tufts \\
\hline Leaf margin & entire & $\begin{array}{l}\text { entire, eroded } \\
\text { towards the apex }\end{array}$ & finely crenulate & finely crenulate \\
\hline $\begin{array}{l}\text { Rows of differentiated } \\
\text { basal marginal cells }\end{array}$ & 1 & several & several & several \\
\hline $\begin{array}{l}\text { Seta:capsule size } \\
\text { relation }\end{array}$ & $1: 2$ & $1: 2$ & $1: 2$ & $1: 3$ \\
\hline Exostome teeth & 8 , divided at apex & 8 , variably divided & unknown & 8 , divided at apex \\
\hline Endostome & unknown & unknown & unknown & 8 filiform segments \\
\hline Vaginula & unknown & naked & unknown & unknown \\
\hline Calyptra & hairy & few appressed hairs & naked & naked \\
\hline
\end{tabular}
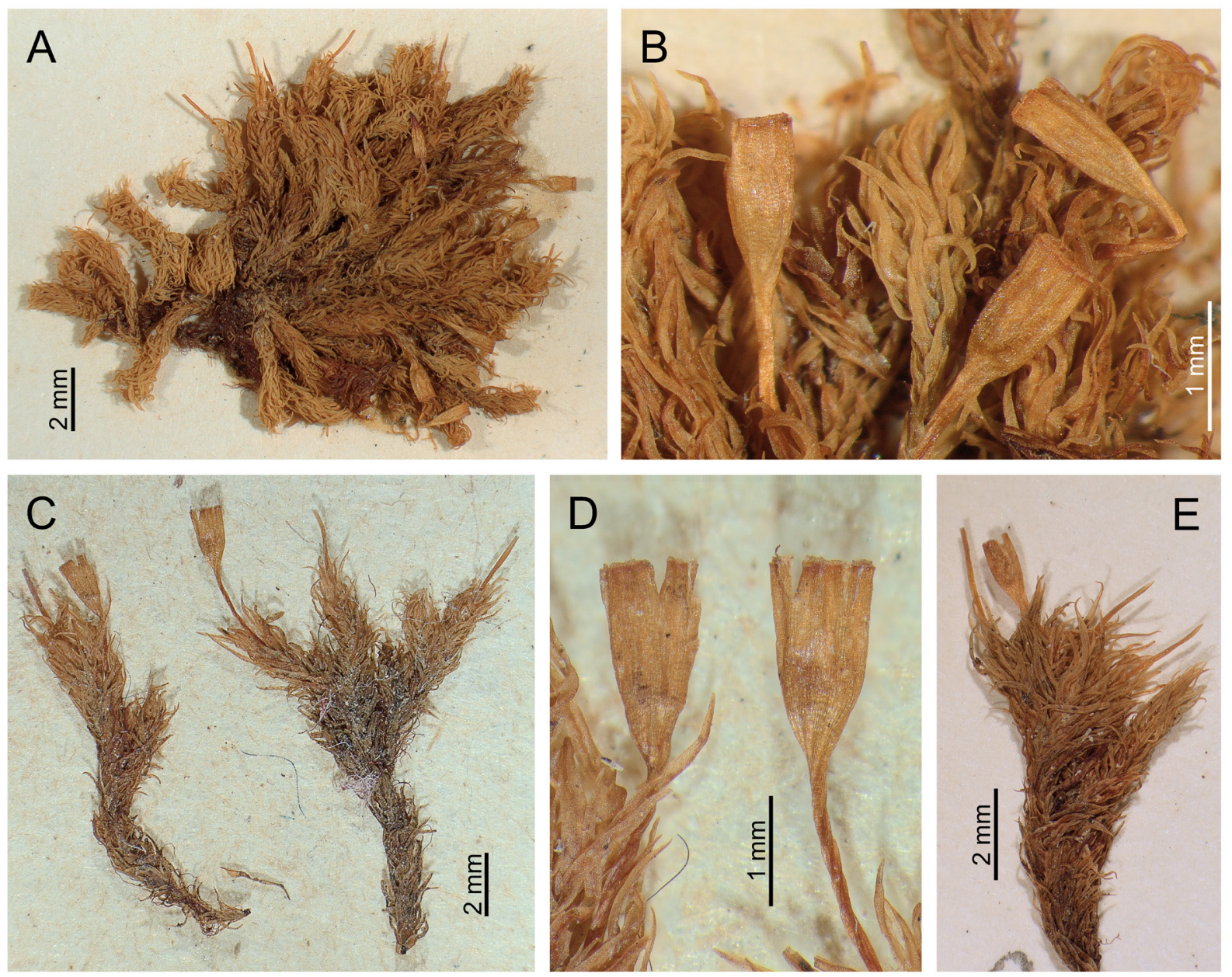

Fig. 1. Examples of the conservation of the type material of Ulota glabella Mitt. A-D. Holotype, consisting of a single specimen in two sheets (A-B from NY[00737690]; C-D from NY[00737691]). E. Isotype (PC[PC0101534]). Photographs by R. Garilleti. 
characters are the papillose costa, usually an overlooked feature, the exostome of eight teeth splitting into 16, papillose and with lines in the upper part, and the endostome of eight or 16 segments somewhat knotted and papillose. It is not possible to safely say on which specimen this peristome description is based, as all the duplicates revised by Malta have lost this structure. One possibility is that it was based on specimens of $U$. eremitensis, as this is the only one that seems to have had perfect peristomes at that time. Nevertheless, it is also possible that Malta did not use original specimens for his description, but rather another intriguing specimen collected by Dusén (S) from Westhoff Island cited in his study. This particular specimen will be discussed later.

The recent revision by Wang \& Jia (2016) reduced the number of accepted species. They concurred with Malta's opinion about the conspecificity of Ulota glabella and U. eremitensis, but considered that " $U$. glabella is virtually identical with $U$. fuegiana in terms of leaf crisping, peristome structure, stomata position and calyptra hairiness" and consequently they listed U. glabella and U. eremitensis under $U$. fuegiana. These authors did not find serrate leaf margins and considered that $U$. fuegiana can have naked calyptrae. In support of their opinion on the variability of the hairiness of the calyptra in U. glabella, they referred to the very sparsely hairy calyptra of the dubious specimen from Westhoff Island cited by Malta (1927).

In summary, currently, there are two interpretations of the two species with naked calyptrae described by Mitten. The first one by Malta (1927), who considers that a single species is involved, different from others in the genus, and the second one by Wang \& Jia (2016), who considers that the forms with naked calyptrae are simply part of the variability in Ulota fuegiana.

\section{Material and methods}

This work is based on the study of the original collections by Hooker (BM, duplicates at E, NY and PC), as well as a significant number of recent collections (MAUAM, NY, VAL), including some from the original locality of $U$. glabella, Hermite Island in the Cape Horn region. In total, 124 modern specimens were studied (Fig. 2, Appendix), 91 of them of U. fuegiana, 27 of U. glabella/U. eremitensis, and, for further comparison, six specimens of $U$. macrocalycina Mitt. All original specimens available were studied, with the only exception being the types of U. luteola, lost in transit in 2013 (Muñoz-Puelles et al. 2017). Acronyms of herbaria follow Index Herbariorum (Thiers continuously updated).

Original specimens were studied under a stereo microscope to avoid damage. Modern collections were also prepared on permanent slides and fully studied under a compound microscope.

\section{Results}

\section{The South American species of Ulota D.Mohr. with naked calyptrae}

Based on the revision by Wang \& Jia (2016), there would only be one species of Ulota in South America with constantly glabrous calyptrae, U. macrocalycina. In addition to this feature, this species has other relevant differentiating characters that strongly support its discrimination: 1) the prostrate growth with upright secondary branches, forming dense tufts; 2$)$ the very short leaves (1.3-1.5 mm long), erect, straight or slightly undulate with blunt to obtuse apices; 3 ) the perichaetial leaves differentiated, longer than the vegetative ones; 4) the stomata located at urn base; 5) the endostome of eight completely smooth and hyaline segments; and 6) the verrucose spores, 30-35 $\mu \mathrm{m}$ wide. The growth form and the position and size of the leaves are uncommon characters sufficient to safely distinguish this characteristic species with a stereoscopic microscope or even a hand-lens. The type material of this species ([Chile] Strait of Magellan, Port Famine; Sep. 1851; Lyall s.n.; holotype: NY[00737693]!; isotypes: BM[BM000879991]!, $\mathrm{BM}$ [BM000879992]!, BM[BM000879993]!) is preserved in good condition, particularly the isotypes at 
BM, but also the holotype, which includes drawings by Mitten. The identity of this species is thus well supported.

Nevertheless, at least one other species with naked calyptrae consistently appears in Patagonia and, especially, in Tierra del Fuego. This plant is clearly different from Ulota macrocalycina and U. fuegiana, even considering the variability of $U$. fuegiana to include naked calyptras, as supported by Wang \& Jia (2016). The more outstanding characters (Figs 3-4) for its discrimination are: 1) leaves undulate to somewhat curved with crenulate-serrate margins and papillose costa; 2) perichaetial leaves differentiated; 3) naked calyptra with a dark beak; 4) stomata present throughout the capsule; 5) brown-orange to pale orange exostome, formed by eight pairs of teeth with a tendency to split, but usually remaining joined at the tips; and 6) brown-orange to pale orange endostome of eight segments, occasionally with remains of incomplete intermediates, ornamented on both sides with irregular small and compact tufts of very high papillae.

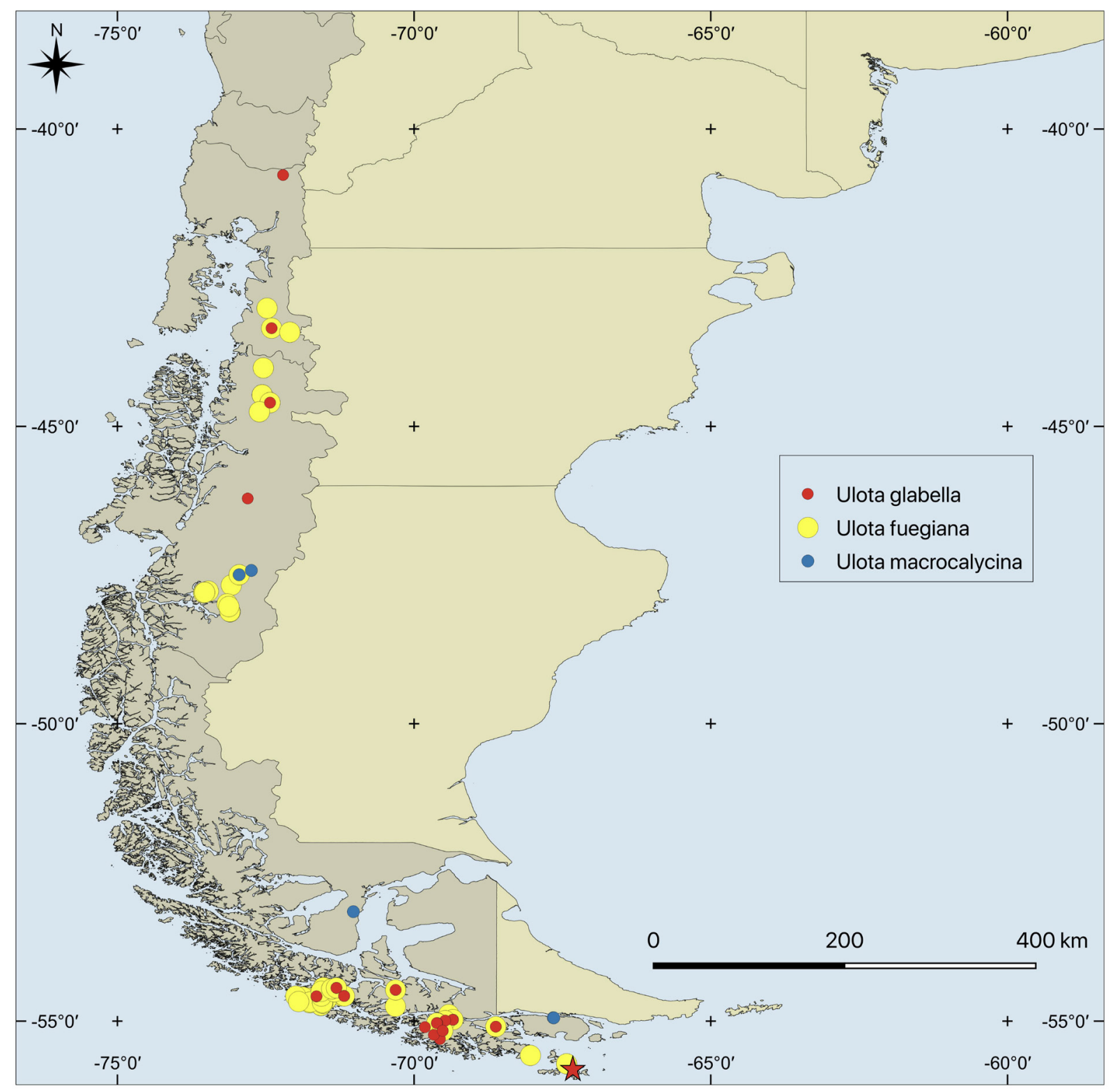

Fig. 2. Origin of the studied specimens. The locus classicus of Ulota glabella Mitt. is marked with a star. 
Table 2. Main differential characters between Ulota glabella Mitt. and U. fuegiana Mitt.

\begin{tabular}{|c|c|c|}
\hline & U. glabella & U. fuegiana \\
\hline Leaf margin & crenate-denticulate & entire \\
\hline Leaf costa & papillose & smooth \\
\hline Perichaetial leaves & $\begin{array}{c}\text { as long as vegetative leaves, } \\
\text { with sheathing base }\end{array}$ & $\begin{array}{l}\text { longer than vegetative leaves, } \\
\text { without sheathing base }\end{array}$ \\
\hline Calyptra & naked & variably hairy, hairs short and papillose \\
\hline Lid basal ring & broad and red & narrow and orange \\
\hline Stomata & $\begin{array}{l}\text { from urn base to near mouth, } \\
\text { entering neck }\end{array}$ & $\begin{array}{l}\text { in the upper } 2 / 3 \text { of the urn, } \\
\text { mainly in central area }\end{array}$ \\
\hline $\begin{array}{l}\text { Exostome color } \\
\text { and configuration }\end{array}$ & $\begin{array}{l}\text { brown-orange to pale orange; } \\
\text { trabeculae not developed }\end{array}$ & $\begin{array}{l}\text { whitish to yellowish; } \\
\text { trabeculae well developed }\end{array}$ \\
\hline $\begin{array}{l}\text { Exostome position } \\
\text { when dry }\end{array}$ & $\begin{array}{l}\text { recurved against exothecium } \\
\text { but not applied }\end{array}$ & $\begin{array}{c}\text { recurved and applied against } \\
\text { exothecium }\end{array}$ \\
\hline $\begin{array}{l}\text { Ornamentation of } \\
\text { external side of } \\
\text { teeth }\end{array}$ & $\begin{array}{c}\text { reticule well developed from base, } \\
\text { upper } 1 / 3-1 / 4 \text { with aligned crests and } \\
\text { papillae, sometimes more uniformly } \\
\text { papillose }\end{array}$ & $\begin{array}{l}\text { reticule somewhat convex and } \\
\text { papillose at lower } 1 / 2-2 / 3 \text {, but with } \\
\text { scattered or longitudinally aligned } \\
\text { papillae upwards }\end{array}$ \\
\hline $\begin{array}{l}\text { Endostome } \\
\text { configuration }\end{array}$ & $\begin{array}{l}8+\mathrm{n} \text {, brown-orange to pale orange, } \\
\text { usually thin, filiform and fragile, but } \\
\text { sometimes thicker and persistent }\end{array}$ & $\begin{array}{l}\text { 8, whitish or hyaline, } \\
\text { filiform and fragile }\end{array}$ \\
\hline $\begin{array}{l}\text { Endostome } \\
\text { ornamentation }\end{array}$ & $\begin{array}{l}\text { upper } 1 / 2 \text { with tufts of papillae, } \\
\text { rarely more homogeneously papillose; } \\
\text { with trabeculae }\end{array}$ & $\begin{array}{l}\text { variably papillose, usually almost } \\
\text { smooth, sometimes coralloid in } \\
\text { appearance; without trabeculae }\end{array}$ \\
\hline
\end{tabular}

\section{Reinterpretation of Ulota glabella Mitt.}

The morphological similarities between the second South American species of Ulota with naked calyptrae and the protologue of $U$. glabella (Mitten 1860) or the more precise description and drawings by Malta (1927) suggest that they are the same species. On the other hand, the analyses of abundant modern specimens show that $U$. fuegiana and $U$. glabella are actually two distinct species that are well distinguished by a set of characters (Table 2, Fig. 4), of which the most important are the hairiness of the calyptrae, the color of the peristomes, the endostome ornamentation, the highly developed exostomial trabeculae in $U$. fuegiana, and the papillosity of the leaf margin and costa in U. glabella. Of these, the characters with the greatest discriminatory value are the peristomial ones.

The holotype of $U$. eremitensis (NY[00737687]!) preserves remains of the peristome, including basal portions of endostome segments. Although the state of the material discourages the use of microscopic preparations to analyze these structures, the stereoscopic microscope shows that the segments are colored in the same way as those of $U$. glabella. The main difference between $U$. glabella and $U$. eremitensis as defined by Mitten (1860) was the size relationship between capsule and seta (1:2 in the former and $1: 3$ in the latter). In our study of recent specimens, we found a continuous gradation between both extremes, supporting Malta's view of a single variable species. Nevertheless, some differences in the peristome coloration and ornamentation are found along this size gradient and it cannot be discarded that $U$. eremitensis may be a different species. More intensive studies with an integrative taxonomic approach are needed to answer this issue. Until these studies can be completed, we consider U. glabella and $U$. eremitensis to belong to the same taxon. 


\title{
Species description
}

Ulota glabella is a morphologically complex species, with overall similarities not only to U. fuegiana but also to U. pusilla Malta and U. macrodontia Dusén ex Malta. The characters listed in Table 2 that differentiate it from $U$. fuegiana are only part of the morphological complexity of $U$. glabella and are not useful to discriminate it from other species. To better delimit U. glabella, we provide a complete description here.

\author{
Division Bryophyta Schimp. \\ Subdivision Bryophytina Engl. \\ Class Bryopsida McClatchie \\ Subclass Bryidae Engl. \\ Superorder Bryanae Goffinet \& W.R. Buck \\ Order Orthotrichales Dixon \\ Family Orthotrichaceae Arn. \\ Tribe Orthotricheae Engl. \\ Genus Ulota D.Mohr. \\ Ulota glabella Mitt. \\ Figs 1, 3, 4A-D
}

Journal of the Proceedings of the Linnean Society, Botany 4: 76 (Mitten 1860). Type: CHILE • [Región de Magallanes y de la Antártica Chilena: Provincia Antártica Chilena, Comuna de Cabo de Hornos] Hermite island, Cape Horn; 19 Sep.-7 Nov. 1842; J.D. Hooker 141a; holotype: NY[00737690]!, NY[00737691]!; isotypes: BM[BM000919960]!, E[E00052655]!, E[E00052673]!, PC[PC0101534]!, PC[PC0108133]!. Epitype: CHILE - Región de Magallanes y de la Antártica Chilena: Comuna de Cabo de Hornos, Parque Nacional Alberto de Agostini, Isla Hoste, E side of Estero Fouqué, opposite Punta Blanco near river draining small lake; 55 $09^{\prime} 49^{\prime \prime} \mathrm{S}, 069^{\circ} 31^{\prime} 00^{\prime \prime} \mathrm{W}$; 2-15 m a.s.1; on Nothofagus betuloides; 21 Jan. 2012; R. Garilleti 2012-077A; MAUAM[5160], here designated (for images of details of the epitype, see Figs 3 and 4B, D).

U. eremitensis Mitt., Journal of the Proceedings of the Linnean Society, Botany 4: 76 (Mitten 1860). Type: CHILE - [Región de Magallanes y de la Antártica Chilena: Provincia Antártica Chilena, Comuna de Cabo de Hornos] Hermite island, Cape Horn; 19 Sep.-7 Nov. 1842; J.D. Hooker 141, p.p.; holotype: NY[00737687]!.

U. hermitei Besch., Mission Scientifique du Cap Horn 1882-1883, Vol. 5 (Botanique): 274 (Bescherelle 1889), nom. illeg., type of earlier name included.

\section{Other material studied}

CHILE - Región Aysén del General Carlos Ibáñez del Campo • Provincia de Aysén: Comuna de

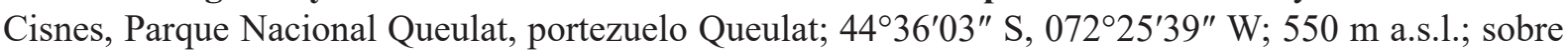
Ribes magellanicum; 28 Dec. 2016; R. Garilleti 2016-235b; collected by R. Garilleti and F. Lara; VALBriof • Provincia de General Carrera: Comuna de Río Ibáñez, Ruta Austral (7), $2.9 \mathrm{~km}$ al S de Puente Las Ovejas, ca valle del río Murta; $46^{\circ} 12^{\prime} 48^{\prime \prime}$ S, $72^{\circ} 48^{\prime} 13^{\prime \prime}$ W; 325 m a.s.l.; ramas de Fuchsia magellanica; 31 Dec. 2016; F. Lara 1612/117; collected by F. Lara and R. Garilleti; MAUAM. - Región de Los Lagos - Provincia de Palena: Comuna de Chaitén, Parque Nacional Corcovado, portezuelo Moraga; 4320'59" S, 072²4'04" W; 600 m a.s.1.; Ribes magellanicum; 25 Dec. 2016; R. Garilleti 2016-193f; collected by R. Garilleti and F. Lara; VAL-Briof - Comuna de Puyehue, Parque Nacional Puyehue, ladera S del volcán Haique, proximidades del complejo Antillanca; 4046'28" S, 072 12'29" W; 10351050 m a.s.l.; cara inferior de ramillas horizontales de Nothofagus pumilio; 14 Jan. 2017; R. Garilleti 
2017-102e; collected by R. Garilleti and F. Lara; VAL-Briof. - Región de Magallanes y de la Antártica Chilena • Provincia Antártica Chilena: Comuna Cabo de Hornos, Parque Nacional Alberto de Agostini, Isla Grande de Tierra del Fuego, extremo NE del Seno Aragay, en el istmo de la Península de Brecknock;

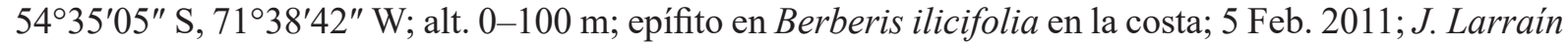
33961, p.p.; NY • Comuna Cabo de Hornos, Parque Nacional Alberto de Agostini, Isla Grande de
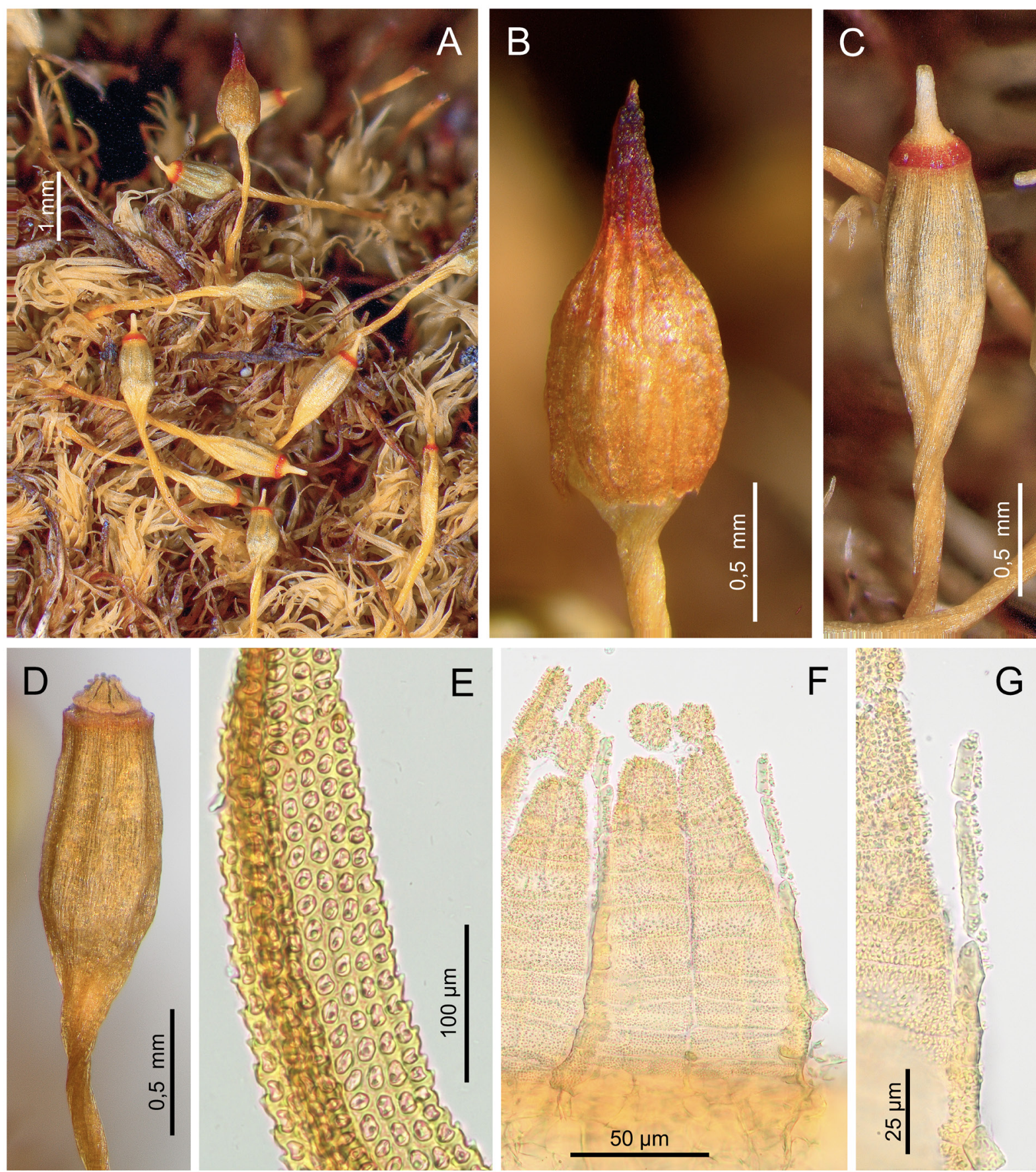

Fig. 3. Ulota glabella Mitt. Details from the epitype (R. Garilleti 2012-077A). A. Habit with operculate capsules. B. Calyptra. C. Operculate capsule, note the broad red basal ring of the lid. D. Capsule immediately after detachment of the lid. E. Crenulate-serrate leaf margin. F. Peristome. G. Detail of the endostome ornamentation. Photographs by R. Garilleti. 


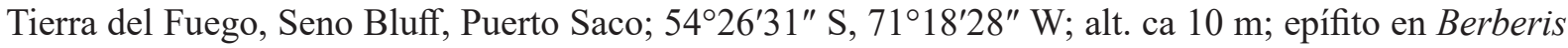
microphylla junto al río; 20 Jan. 2011; J. Larraín 33243, p.p.; NY - Comuna Cabo de Hornos: Isla

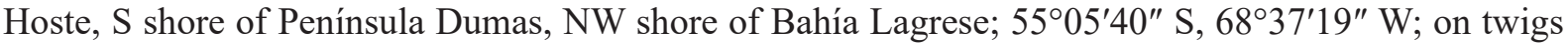
of Berberis; 24 Jan. 2005; W.R. Buck 48079, p.p.; NY • Comuna Cabo de Hornos: Parque Nacional Alberto de Agostini, Isla Grande de Tierra del Fuego, NE end of Seno Aragay at isthmus to Península Brecknock; 54³4'59' S, 71 ${ }^{\circ} 38^{\prime} 38^{\prime \prime}$ W; 0-50 m a.s.1.; on Berberis; 5 Feb. 2011; W.R. Buck 57494; NY • Comuna Cabo de Hornos: Parque Nacional Alberto de Agostini, Isla Grande de Tierra del Fuego, ENE

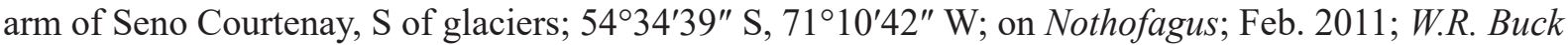
57325; NY • ibid.; on Nothofagus; Feb. 2011; W.R. Buck 57300, p.p.; NY • ibid.; on Nothofagus; Feb. 2011; W.R. Buck 57308, p.p.; NY・ibid.; on Nothofagus; Feb. 2011; W.R. Buck 57331; NY • Comuna Cabo de Hornos: Parque Nacional Alberto de Agostini, Isla Grande de Tierra del Fuego, S of Canal

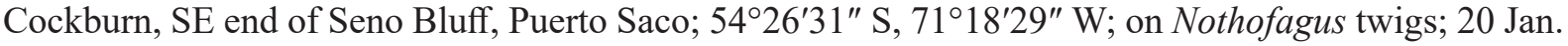
2011; W.R. Buck 56717, p.p.; NY• ibid.; on Nothofagus twigs; 20 Jan. 2011; W.R. Buck 56725, p.p.; NY - Comuna de Timaukel, Isla Grande de Tierra del Fuego, Parque Nacional Alberto de Agostini,

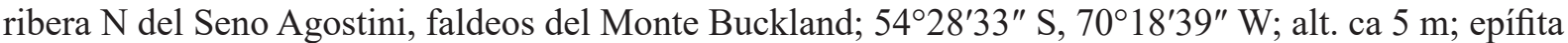
en Gaultheria en el borde del bosque, en la costa; 25 Jan. 2011; J. Larraín 33502, p.p.; collected by J. Larraín and J. Shevock; NY - Comuna de Cabo de Hornos, Parque Nacional Alberto de Agostini, Isla Hoste, E side of Estero Fouqué, opposite Punta Blanco near river draining small lake; $55^{\circ} 09^{\prime} 49^{\prime \prime} \mathrm{S}$, 069 $31^{\prime} 00^{\prime \prime}$ W; $2-15$ m a.s.1.; on Nothofagus betuloides; 1 Jan. 2012; W.R. Buck 58636; NY • Comuna de Cabo de Hornos, Parque Nacional Alberto de Agostini, isla Hoste, N shore of Península Cloue, Caleta Coloane; 55 06'09" S, 069 49'01" W; 5-25 m a.s.1.; small branches of Nothofagus betuloides; 22 Jan. 2012; R. Garilleti 2012-080C; VAL-Briof • Comuna de Cabo de Hornos, Parque Nacional Alberto de Agostini, Isla Hoste, NW shore of Península Rous at eastern end of unnamed sound sharing its mouth with that of Estero Webb, terminating in river draining glacial lakes; $55^{\circ} 18^{\prime} 07^{\prime \prime} \mathrm{S}, 069^{\circ} 33^{\prime} 51^{\prime \prime} \mathrm{W} ; 2-15 \mathrm{~m}$ a.s.1.; branches of Berberis ilicifolia; 23 Jan. 2012; R. Garilleti 2012-090bA; VAL-Briof - Comuna de Cabo de Hornos, Parque Nacional Alberto de Agostini, Isla Hoste, Península Cloue, unnamed arm of Estero Webb; 55 $13^{\prime} 55^{\prime \prime} \mathrm{S}, 069^{\circ} 40^{\prime} 01^{\prime \prime} \mathrm{W} ; 5-15 \mathrm{~m}$ a.s.1.; on Nothofagus betuloides; 23 Jan. 2012; R. Garilleti 2012-082; VAL-Briof • Comuna de Cabo de Hornos, Parque Nacional Alberto de Agostini, SE coast of Isla Gordon in unnamed sound ca $10 \mathrm{~km} \mathrm{~W}$ of eastern tip of island on the Brazo Sudoeste

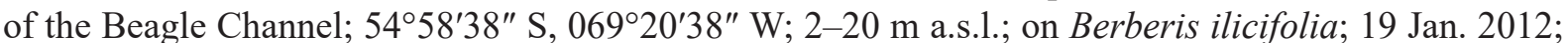
R. Garilleti 2012-025A; VAL-Briof • ibid.; on Berberis ilicifolia; 19 Jan. 2012; R. Garilleti 2012-027A; VAL-Briof • ibid.; on Berberis ilicifolia; 19 Jan. 2012; R. Garilleti 2012-031A; VAL-Briof • Comuna de Cabo de Hornos, Parque Nacional Alberto de Agostini, SE coast of Isla Gordon in unnamed sound NW

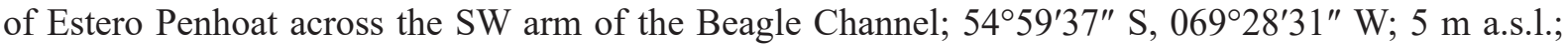
on Berberis buxifolia in the shoreline; 20 Jan. 2012; R. Garilleti 2012-035C; VAL-Briof - Comuna de Cabo de Hornos, Parque Nacional Alberto de Agostini, south-central coast of Isla Gordon, Caleta

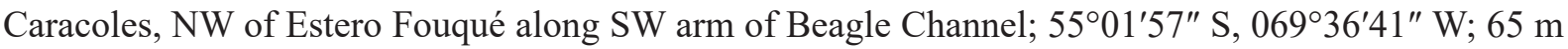

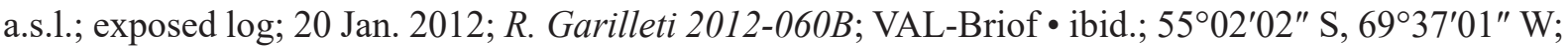
20 Jan. 2012; W.R. Buck 58550; NY • Comuna de Cabo de Hornos, Parque Nacional Alberto de Agostini, north-central coast of Isla Hoste, ca $5 \mathrm{~km} \mathrm{~W}$ of the eastern tip of Isla Gordon along Brazo Sudoeste of

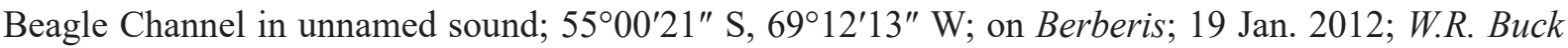
58398; NY.

\section{Description}

Plants growing in small cushions. Leaves non crisped, undulate to somewhat curved, (2.0-)2.5-3.15 × 0.4-0.6 mm; leaf margin crenulate-serrate, more strongly towards apex, with protruding papillae. Costa dorsal cells papillose. Lamina cells with $1(-2)$ single or ramified papillae. Differentiated basal marginal cells in more than five rows. Perichaetial leaves differentiated, with sheathing base, abruptly narrowed towards lamina and with blunt to obtuse apex. Vaginula naked, 0.4-0.7 mm long. Calyptra naked with dark beak, $1.5-1.9 \mathrm{~mm}$ long. Seta (2.75-)4.0-5.7 $\mathrm{mm}$ long. Capsule fusiform when dry and 
full of spores, cylindrical when dry and empty, somewhat wider below its middle, 1.35-2.2 mm long including neck; ribs moderately marked, concolorous with rest of exothecium. Stomata scattered from urn base and neck to near capsule mouth. Exothecial bands thin, scarcely differentiated, formed by 2-3 cell rows with walls not strongly thickened. Operculum plane-convex, with broad reddish basal rim. Peristome double. Exostome of 8 pairs of teeth with tendency to split, but usually remaining joined at tips, brown-orange, sometimes paler, 230-325(-356) $\mu \mathrm{m}$ long; external side (outer peristome layer = OPL) ornamented in basal section by reticule with tall papillae, in upper $1 / 3-1 / 4$ with longitudinal crests and aligned papillae, sometimes uniformly papillose; inner side (primary peristome layer $=$ PPL) with scattered tall papillae, becoming denser at tips and sometimes longitudinally aligned at base. Endostome
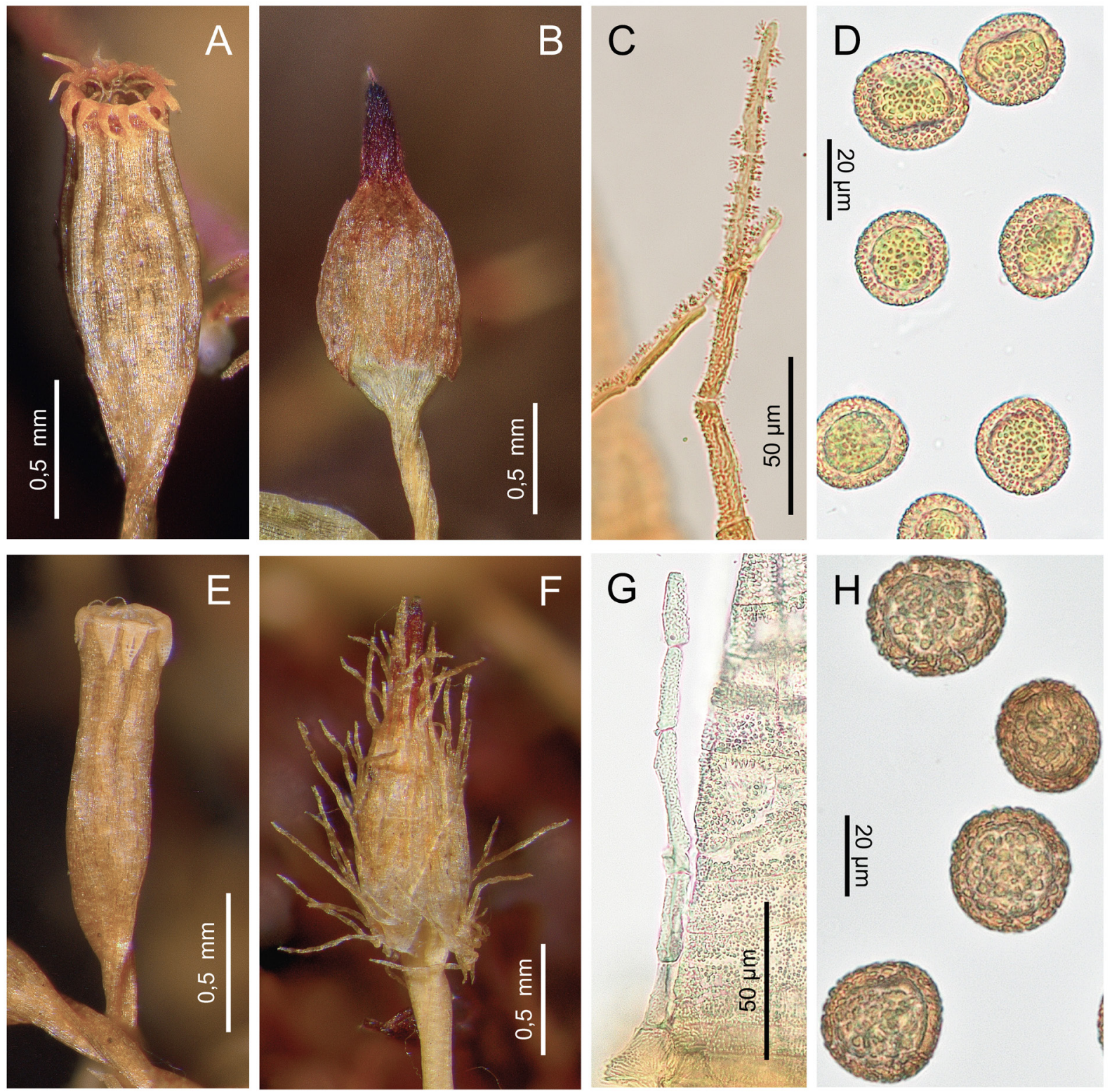

Fig. 4. Comparison between Ulota glabella Mitt. (A-D) and U. fuegiana Mitt. (E-H). A, E. Capsules, notice the difference in coloration and structure of exostome teeth. B, F. Calyptrae. C, G. Endostome ornamentation and coloration. D, H. Spore ornamentation. Each pair of images are at the same magnification. A, C from W.R. Buck 57300; B, D from the epitype (R. Garilleti 2012-077A); E-H from R. Garilleti 2012-020. Photographs by R. Garilleti. 
of 8 segments, occasionally with remains of incomplete intermediates, brown-orange, sometimes paler, filiform and fragile, sometimes wider and more persistent; uni-biseriate at base, uniseriate above, almost as long as teeth; external side (PPL) smooth in basal $2 \frac{2}{3}$, in the upper $1 / 3$ smooth but ornamented with clusters of high papillae, with appearance of tufts, which can protrude laterally, much less frequently with lines; inner surface (inner peristome layer = IPL) with base ornamented by low reticulum with coralloid aspect or by papillae, in upper parts smooth and with papillae in clusters as in PPL, rarely more or less homogeneously papillose with these clusters not or hardly developed; trabeculae differentiated. Spores finely papillose, $20-30 \mu \mathrm{m}$ in diameter.

\section{Discussion}

The assimilation of $U$. glabella with $U$. fuegiana by Wang \& Jia (2016) was based on the interpretation that the calyptrae of the latter vary from very hairy to naked and on the lack of serrate margins in the specimens they studied. The two other cited characters, the stomata position and the crisping of the leaves, are more or less variable within this species and, in the case of leaf position, sometimes difficult to describe, which results in the same curvature of leaves being described differently by different authors. The specimens we identified as $U$. glabella have leaves with crenulate-serrate or crenulatepapillose margins (Fig. 3E), exactly like those described by Mitten (1860) and drawn by Malta (1927). Concerning the development of hairs on the calyptra, although this feature can show variability both in the genus Ulota (Caparrós et al. 2011; Garilleti et al. 2020) and other Orthotricheae (Lara et al. 2020), it rarely displays a complete gradation from hairy to naked calyptrae (Caparrós et al. 2014). Among the numerous specimens of $U$. fuegiana that we have studied, none have been found with naked calyptrae; all of them have short, thick and papillose hairs variably abundant. The identity of the specimen from Westhoff Island with some hairs cited by Malta (1927) and used by Wang \& Jia (2016) in support of their position is doubtful. In addition to the presence of hairy calyptrae, the spores of this specimen (Malta 1927) are noticeably large $(40-50 \mu \mathrm{m})$, far greater in size from those of $U$. fuegiana, which measure, according to our observations, 25-30(-34) $\mu \mathrm{m}$. Such large unicellular spores are found in South America only in U. magellanica (Mont.) A.Jaeger and U. pusilla. The discriminant characters for U. magellanica are discussed in Garilleti et al. (2015). Ulota pusilla is morphologically close to $U$. glabella, as it has crenate-serrate leaf margins, an orange-tinged peristome and a similar shape of the capsule. Its endostome has $8+n$ segments, with the intermediates sometimes well-developed. It is not impossible that the sample from Westhoff Island, used by Malta to describe the spores and peristomes of $U$. glabella, may in fact correspond to U. pusilla. Malta himself pointed out the great similarity of this specimen with the latter species. Confirmation of the identity of the Werthoff Island specimen has not been possible at the present time, since the Stockholm Herbarium is currently under renovation and access to its collections is closed.

\section{An epitype for Ulota glabella Mitt.}

As shown in this paper, U. glabella is a distinct species with clear morphological characters discriminating it from U. fuegiana. Nevertheless, the holotype of U. glabella was already in imperfect condition (Fig. 1A-D) when this species was published and today all the extant isotypes are similarly damaged (e.g., Fig. 1E). Thus, the discriminatory characters for this species, particularly those differentiating it from U. fuegiana, are lost, suggesting that recent confusion with this species has likely occurred because of the poor condition of the type material, which prevents any critical comparison between the species.

Since all original material is "demonstrably ambiguous and cannot be critically identified for purposes of the precise application of the name to a taxon" (ICN Art. 9.9, Turland et al. 2018), it is necessary to select an epitype with well-preserved differentiating features, mainly those of the peristome, to serve as an interpretative type that fixes the application of this name. We have chosen as epitype a specimen collected by R. Garilleti from Hoste Island, Tierra del Fuego archipelago (Chile), belonging to the 
same biogeographic region as Cape Horn. Details of this specimen as well as the holotype and isotypes supported by it are in the description of the species. It is completed with the details in Figs 3 and 4B, D.

\section{Acknowledgements}

We thank the curators of BM, E, NY, and PC for providing material used in this study. A heartfelt thanks to William R. Buck for kindly inviting the first author to the 2012 expedition to the Cape Horn region, and for sending his own samples from that and other campaigns. The Chilean Corporación Nacional Forestal (CONAF) gave to RG and FL authorization to collect mosses in the territories managed by this national service and they are deeply thanked for that. We thank Sarah Young for her revision of the English language. This research was funded by the Spanish Ministries of Economy and Competitiveness (grant CGL2013-43246-P), and Economy, Industry and Competitiveness (grant CGL2016-80772-P).

\section{References}

Bescherelle É. 1889. II. - Mousses. In: Mission Scientifique du Cap Horn 1882-1883, Vol. 5 (Botanique): 253-312. Gauthier-Villars, Paris.

Caparrós R., Garilleti R., Price M.J., Mazimpaka V. \& Lara F. 2016. Tackling a long-standing problem: Typification of Orthotrichum crispum, Ulota crispula and Ulota intermedia (Bryopsida: Orthotrichaceae). Taxon 65 (4): 862-866. https://doi.org/10.12705/654.11

Caparrós R., Garilleti R. \& Lara F. 2014. Ulota D.Mohr. In: Guerra J., Cano M.J. \& Brugués M. (eds) Flora Briofitica Ibérica, Vol. V. Orthotrichales: Orthotrichaceae; Hedwigiales: Hedwigiaceae; Leucodontales: Fontinalaceae, Climaciaceae, Anomodontaceae, Cryphaeaceae, Leptodontaceae, Leucodontaceae, Neckeraceae; Hookeriales: Hypopterygiaceae, Hookeriaceae, Leucomiaceae, Pilotrichaceae: 34-50. Universidad de Murcia \& Sociedad Española de Briología, Murcia.

Caparrós R., Lara F., Long D.G., Mazimpaka V. \& Garilleti R. 2011. Two new species of Ulota (Orthotrichaceae, Bryopsida) with multicellular spores, from the Hengduan Mountains, Southwestern China. Journal of Bryology 33 (3): 210-220. https://doi.org/10.1179/1743282011Y.0000000008

Garilleti R., Mazimpaka V. \& Lara F. 2015. Ulota larrainii (Orthotrichoideae, Orthotrichaceae, Bryophyta) a new species from Chile, with comments on the worldwide diversification of the genus. Phytotaxa 217 (2): 133-144. https://doi.org/10.11646/phytotaxa.217.2.3

Garilleti R., Muñoz-Puelles L., Mazimpaka V. \& Lara F. 2016. A new lectotypification of Ulota macrodontia Dusén ex Malta (Orthotrichaceae, Bryophyta). Journal of Bryology 38 (4): 355-359. https://doi.org/10.1080/03736687.2016.1170320

Garilleti R., Albertos B., Draper I., Calleja J.A., Mazimpaka V. \& Lara F. 2020. Two complex typifications and a new name to unravel Ulota germana sensu Malta non (Mont.) Mitt. (Orthotrichaceae). The Bryologist 123 (2): 163-178. https://doi.org/10.1639/0007-2745-123.2.163

Hooker J.D. 1847. I. Flora Antarctica. Part II., Botany of Fuegia, the Falklands, Kerguelen's Land, etc. In: The Botany of the Antarctic voyage of H.M. discovery ships Erebus and Terror in the years 18391843 under the command of Captain Sir James Clark Ross, Kt., R.N., F.R.S., \&c.: 208-405. Reeve Brothers, London.

Huxley L. 1918. Life and letters of sir Joseph Dalton Hooker O.M., G.C.S.I. Based on materials collected and arranged by Lady Hooker. Volume I. John Murray, London.

Lara F., Draper I., Flagmeier M., Calleja J.A., Mazimpaka V. \& Garilleti R. 2020. Let's make Pulvigera great again: re-circumscription of a misunderstood group of Orthotrichaceae that diversified in North America. Botanical Journal of the Linnean Society 193: 180-206.

https://doi.org/10.1093/botlinnean/boaa013 
Malta N. 1927. Die Ulota-Arten Süd-Amerikas. Acta Horti Botanici Universitatis Latviensis 2 (2-3): $165-208$.

Mitten W. 1860. Description of some new species of musci from New Zealand and other parts of the Southern Hemisphere, together with an enumeration of the species collected in Tasmania by William Archer, Esq. Journal of the Proceedings of the Linnean Society. Botany 4: 64-100.

Muñoz-Puelles L., Lara F., Mazimpaka V. \& Garilleti R. 2017. Vindication of Ulota pygmaeothecia (Orthotrichaceae, bryophyta). Phytotaxa 317 (3): 161-174. https://doi.org/10.11646/phytotaxa.317.3.1

Natural History Museum. 2020. Data Portal query created at 2020-05-29.

https://doi.org/10.5519/qd.mzw416b8

Ross J.C. 1847. A voyage of discovery and research in the Southern and Antarctic regions, during the years 1839-43, Vol. II. John Murray, London.

Thiers B. continuously updated. Index Herbariorum: a global directory of public herbaria and associated staff. New York Botanical Garden's Virtual Herbarium.

Available from http://sweetgum.nybg.org/science/ih/ [accessed 23 Nov. 2020].

Turland N.J., Wiersema J.H., Barrie F.R., Greuter W., Hawksworth D.L., Herendeen P.S., Knapp S., Kusber W.-H., Li D.-Z., Marhold K., May T.W., McNeill J., Monro A.M., Prado J., Price M.J. \& Smith G.F. 2018. International Code of Nomenclature for Algae, Fungi, and Plants (Shenzhen Code) Adopted by the Nineteenth International Botanical Congress Shenzhen, China, July 2017. Koeltz Botanical Books, Glashütten. https://doi.org/10.12705/Code.2018

Wang Q. \& Jia Y. 2016. A taxonomic revision of Ulota Mohr (Orthotrichaceae) in South and Central America. Plant Diversity 38 (2): 65-88. https://doi.org/10.1016/j.pld.2016.03.003

Manuscript received: 20 July 2020

Manuscript accepted: 28 September 2020

Published on: 3 December 2020

Topic editor: Frederik Leliaert

Desk editor: Radka Rosenbaumová

Printed versions of all papers are also deposited in the libraries of the institutes that are members of the EJT consortium: Muséum national d'histoire naturelle, Paris, France; Meise Botanic Garden, Belgium; Royal Museum for Central Africa, Tervuren, Belgium; Royal Belgian Institute of Natural Sciences, Brussels, Belgium; Natural History Museum of Denmark, Copenhagen, Denmark; Naturalis Biodiversity Center, Leiden, the Netherlands; Museo Nacional de Ciencias Naturales-CSIC, Madrid, Spain; Real Jardín Botánico de Madrid CSIC, Spain; Zoological Research Museum Alexander Koenig, Bonn, Germany; National Museum, Prague, Czech Republic. 
Appendix. Additional material examined.

Ulota fuegiana Mitt.

CHILE - Región Aysén del General Carlos Ibáñez del Campo • Provincia Capitán Prat: Comuna de Tortel, Caleta Tortel, en las pasarelas del pueblo; 47 $47^{\prime} 57^{\prime \prime} \mathrm{S}, 7^{\circ} 32^{\prime} 49^{\prime \prime} \mathrm{W}$; epífito en gran Nothofagus dombeyi junto a la pasarela; 20 Jan. 2007; J. Larraín 26927F; collected by J. Larraín and R. Vargas; VAL-Briof - camino a Caleta Tortel, primeros km pasado bifurcación a Yungay; 47 46'18" S, 73²0'48" W; epífito en Baccharis; 19 Jan. 2007; J. Larraín 26840; collected by J. Larraín and R. Varga; VAL-Briof • Caleta Tortel, pasarelas mirador Cerro Vigía a Cerro Lavandera; 474' $32^{\prime \prime}$ S, $73^{\circ} 31^{\prime} 48^{\prime \prime}$ W; tundra con coihues (Nothofagus dombeyi), tronco de Nothofagus dombeyi; 2 Jan. 2017; R. Garilleti 2017-011b; collected by R. Garilleti \& F. Lara; VAL-Briof • ibid.; tundra con coihues (Nothofagus dombeyi), tronco de Nothofagus dombeyi; 2 Jan. 2017; R. Garilleti 2017-012f; collected by R. Garilleti \& F. Lara; VAL-Briof • cruzando pasarela Lago Vargas, en bosque de Nothofagus dombeyi-N. antarctica-

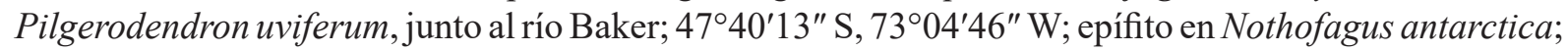
19 Jan. 2007; J. Larraín 26834; collected by J. Larraín and R. Varga; VAL-Briof • cruzando pasarela Río Ñadis; 47²9'49" S, 72 56'51" W; en bosque de Nothofagus dombeyi; epífito en Nothofagus dombeyi; 19 Jan. 2007; J. Larrain 26796C; collected by J. Larraín and R. Varga; VAL-Briof - Lago Quetru, alrededores de casa de Nahuel; 48 $07^{\prime} \mathrm{S}, 7^{\circ} 06^{\prime} \mathrm{W}$; en el suelo pedregoso; 23 Mar. 2007; J. Larraín 27123A; collected by J. Larraín and R. Varga; VAL-Briof • Lago Quetru, playa junto a bosque prístino de Nothofagus dombeyi-Drimys winteri-Podocarpus nubigena en ribera, plano; $48^{\circ} 06^{\prime} 47^{\prime \prime} \mathrm{S}$, 7306'16" W; epífito en Gaultheria; 13 Mar. 2007; J. Larraín 27869A; collected by J. Larraín and

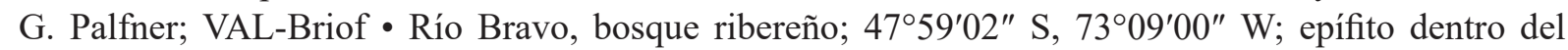
bosque; 19 Jan. 2007; J. Larraín 27033; collected by J. Larraín and R. Varga; VAL-Briof • sector Lago Leal, turbera junto al camino; 48 $08^{\circ} 41^{\prime} 47^{\prime \prime}$ S, $73^{\circ} 07^{\prime} 18^{\prime \prime} \mathrm{W}$; epífito en Berberis; 13 Mar. 2007; J. Larraín 27820A3; collected by J. Larraín and G. Palfner; VAL-Briof • Provincia de Aysén: Comuna de Cisnes, Parque Nacional Queulat, entrada al Ventisquero Colgante; 44²8'17" S, 072 $33^{\prime} 34^{\prime \prime}$ W; bosque musgoso de Nothofagus betuloides, sobre Nothofagus dombeyi; 28 Dec. 2016; R. Garilleti 2016-227b; collected by R. Garilleti \& F. Lara; VAL-Briof • ibid.; sobre Gaultheria mucronata; 28 Dec. 2016; $R$. Garilleti 2016-228f; collected by R. Garilleti \& F. Lara; VAL-Briof • ibid.; sobre Weinmannia trichosperma; 28 Dec. 2016; R. Garilleti 2016-226c; collected by R. Garilleti \& F. Lara; VAL-Briof - ibid.; sobre Weinmannia trichosperma; 28 Dec. 2016; R. Garilleti 2106-229a; collected by R. Garilleti \& F. Lara; VAL-Briof - ibid.; sobre Caldcluvia paniculata; 28 Dec. 2016; R. Garilleti 2016-230d; collected by R. Garilleti \& F. Lara; VAL-Briof • ibid.; ramillas de Nothofagus dombeyi; 28 Dec. 2016; R. Garilleti 2016-231d; collected by R. Garilleti \& F. Lara; VAL-Briof - Comuna de Cisnes, Parque Nacional

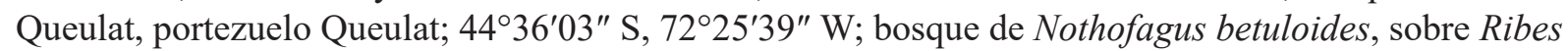
magellanicum; 28 Dec. 2016; R. Garilleti 2016-235c; collected by R. Garilleti \& F. Lara; VAL-Briof •

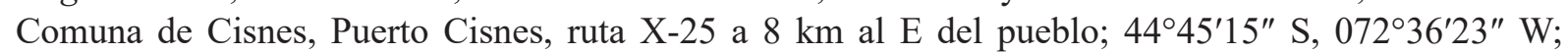
matorral en zona llana, sobre Buxus buxifolia; 29 Dec. 2016; R. Garilleti 2016-236f; collected by R. Garilleti \& F. Lara; VAL-Briof • ibid.; matorral en zona llana, sobre Buxus buxifolia; 29 Dec. 2016; R. Garilleti 2016-237f; collected by R. Garilleti \& F. Lara; VAL-Briof • Comuna de Cisnes, Ruta X-12, a $15 \mathrm{~km}$ al W de La Junta; $44^{\circ} 01^{\prime} 06^{\prime \prime} \mathrm{S}, 072^{\circ} 32^{\prime} 25^{\prime \prime} \mathrm{W}$; bordes de bosque siempreverde alterado y matorral de sustitución de Berberis sp. pl, ramas de Aextoxicon punctatum; 27 Dec. 2016; R. Garilleti 2016-213e; collected by R. Garilleti \& F. Lara; VAL-Briof • Provincia de Palena: Comuna de Chaitén,

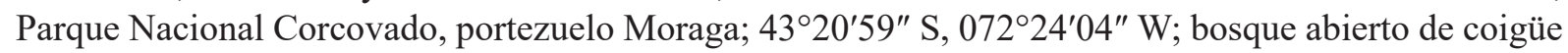
de Magallanes (Nothofagus betuloides), sobre Ribes magellanicum; 25 Dec. 2016; R. Garilleti 2016193g; collected by R. Garilleti \& F. Lara; VAL-Briof - Comuna de Chaitén, proximidades del P.N.

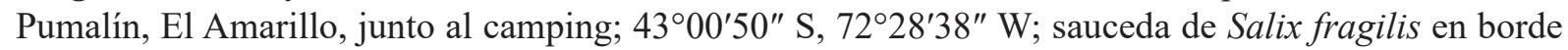
de prado, tronco de Salix fragilis; 25 Dec. 2016; R. Garilleti 2016-191b; collected by R. Garilleti \& F. Lara; VAL-Briof - Comuna de Palena, ruta 231 junto al río Futaleufú, al norte del hotel Raudal; $43^{\circ} 25^{\prime} 05^{\prime \prime} \mathrm{S}, 072^{\circ} 05^{\prime} 35^{\prime \prime} \mathrm{W}$; bosque abierto de coigüe de Magallanes (Nothofagus betuloides), ramas de 
Castanea sativa; 25 Dec. 2016; $R$. Garilleti 2016-196c; collected by R. Garilleti \& F. Lara; VAL-Briof. - Región de Magallanes y de la Antártica Chilena - Provincia Antártica Chilena: Comuna Cabo de Hornos, Parque Nacional Alberto de Agostini, Isla Grande de Tierra del Fuego, ENE arm of Seno Courtenay, S of glaciers; 54 $34^{\prime} 39^{\prime \prime} \mathrm{S}, 71^{\circ} 10^{\prime} 42^{\prime \prime} \mathrm{W}$; wet Nothofagus antarctica forest with numerous small streams and waterfalls, on Berberis; 2 Feb. 2011; W.R. Buck 57274; NY • along the northern shore of Isla Clementina across from the widest part of sound from adjacent Isla Georgiana; 54 $41^{\prime} 31.5^{\prime \prime} \mathrm{S}$, $71^{\circ} 45^{\prime} 32.0^{\prime \prime} \mathrm{W}$; on slope below ridge in a Nothofagus and Drimys stand with streamlet, on Berberis stem and branches in sun; 31 Jan. 2011; J.R. Shevock 37354; NY • along the southeastern shore of Isla Basket at Bahia Murray between Punta Vera and Punta Liliana; 54 $44^{\prime} 20.0^{\prime \prime} \mathrm{S}, 71^{\circ} 34^{\prime} 09.0^{\prime \prime} \mathrm{W}$; at tidal area of sound in a Nothofagus and Drimys stand with Gaultheria shrubs, on branches of Gaultheria shrubs in sun; 1 Feb. 2011; J.R. Shevock 37395, p.p.; NY • Comuna Cabo de Hornos, Parque Nacional Alberto de Agostini, Isla Grande de Tierra del Fuego, NE end of Seno Aragay at isthmus to Península Brecknock;

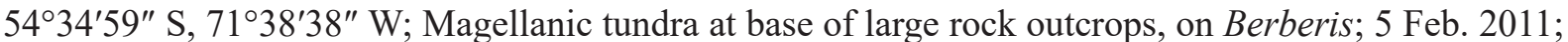
W.R. Buck 57489; NY • Comuna Cabo de Hornos, Parque Nacional Alberto de Agostini, Isla Grande de

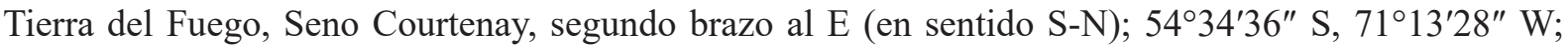
bosque denso de Nothofagus betuloides bajo gran cascada, con río que lo cruza, epífito en Berberis ilicifolia en el interior del bosque; 2 Feb. 2011; J. Larraín 33788; collected by J. Larraín and K. Mighill; NY - Comuna Cabo de Hornos, Parque Nacional Alberto de Agostini, Isla Grande de Tierra del Fuego,

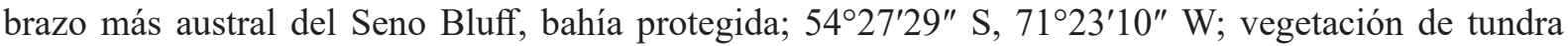
magallánica, pantanos de Astelia pumila-Donatia fascicularis, epífito en Berberis ilicifolia; 20 Jan. 2011; J. Larraín 33278, p.p.; NY • ibid.; epífito en Pilgerodendron uviferum; 20 Jan. 2011; J. Larraín 33276, p.p.; NY • Comuna Cabo de Hornos, Parque Nacional Alberto de Agostini, Isla Grande de Tierra del Fuego, Brazo SW del Seno Chasco, al final del seno, en la costa junto al istmo donde comienza la

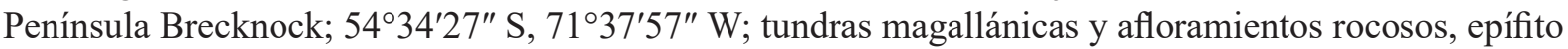
en Chiliotrichum diffusum en la costa; 24 Jan. 2011; J. Larraín 33461; NY • Comuna Cabo de Hornos, Parque Nacional Alberto de Agostini, Isla Grande de Tierra del Fuego, extremo NE del Seno Aragay, en el istmo de la Península de Brecknock; 54 $35^{\circ} 05^{\prime \prime} \mathrm{S}, 71^{\circ} 38^{\prime} 42^{\prime \prime} \mathrm{W}$; tundras en ladera empinada con roca suelta, afloramientos rocosos, y bosquetes de Nothofagus betuloides-Drimys winteri y Pilgerodendron uviferum dispersos, epífito en Berberis ilicifolia en la costa; 5 Feb. 2011; J. Larraín 33961, p.p.; NY • Comuna Cabo de Hornos, Parque Nacional Alberto de Agostini, Isla Grande de Tierra del Fuego,

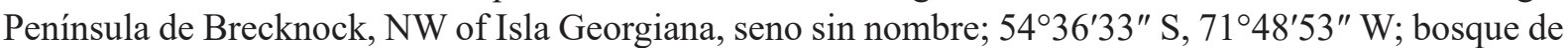
Nothofagus betuloides exp. SW, epifito en Berberis ilicifolia en el interior del bosque; 30 Jan. 2011; J. Larrain 33639; collected by J. Larraín and K. Mighill; NY • Comuna Cabo de Hornos, Parque Nacional Alberto de Agostini, Isla Grande de Tierra del Fuego, Península de Edwards, faldeos al E del Monte Edwards; $54^{\circ} 38^{\prime} 01^{\prime \prime} \mathrm{S}, 71^{\circ} 28^{\prime} 20.5^{\prime \prime} \mathrm{W}$; tundras y bosquetes de Nothofagus betuloides-Drimys winteri, afloramientos rocosos y bloques erráticos, epífito en Nothofagus muerto; 3 Feb. 2011; J. Larraín 33836; NY - Comuna Cabo de Hornos, Parque Nacional Alberto de Agostini, Isla Grande de Tierra del Fuego,

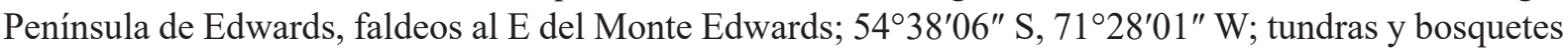
de Nothofagus betuloides-Drimys winteri, afloramientos rocosos y bloques erráticos, tundras junto a la costa, epífito en Berberis ilicifolia en tundras; 3 Feb. 2011; J. Larrain 33824, p.p.; NY • Comuna Cabo de Hornos, Parque Nacional Alberto de Agostini, Isla Grande de Tierra del Fuego, Seno Bluff, Puerto Saco; $54^{\circ} 26^{\prime} 31^{\prime \prime} \mathrm{S}, 71^{\circ} 18^{\prime} 28^{\prime \prime} \mathrm{W}$; playa al sur de la bahía y bosques circundantes, epífito en Berberis microphylla junto al río; 20 Jan. 2011; J. Larraín 33243, p.p.; NY • Comuna Cabo de Hornos, Parque Nacional Alberto de Agostini, Isla Grande de Tierra del Fuego, Seno Bluff, Puerto Saco; 54 26'32" S, 71 $18^{\prime} 23^{\prime \prime}$ W; tundras magallánicas de Astelia pumila y bosques de Nothofagus betuloides-Drimys winteri, epífito en Berberis ilicifolia; 20 Jan. 2011; J. Larraín 33249, p.p.; NY • Comuna Cabo de Hornos, Parque Nacional Alberto de Agostini, Isla Grande de Tierra del Fuego, Seno Courtenay, segundo

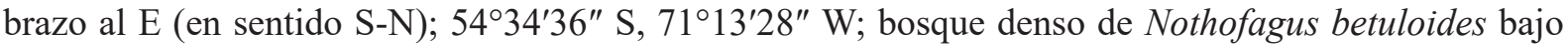
gran cascada, con río que lo cruza, epífito en Berberis ilicifolia en el borde del bosque; 2 Feb. 2011; J. Larraín 33782; collected by J. Larraín and K. Mighill; NY • Comuna Cabo de Hornos, Parque Nacional 
Alberto de Agostini, Isla Grande de Tierra del Fuego, Seno Sargazos, en bahía protegida al fondo del seno, tundras magallánicas con bosquetes de Nothofagus betuloides; $54^{\circ} 26^{\prime} 08^{\prime \prime} \mathrm{S}, 71^{\circ} 31^{\prime} 10^{\prime \prime} \mathrm{W}$; alrededores de la laguna, sobre bloque en tundras; 21 Jan. 2011; J. Larraín 33329; NY • Comuna Cabo de Hornos, Parque Nacional Alberto de Agostini, Isla Grande de Tierra del Fuego, Seno Sargazos, en bahía protegida al fondo del seno, tundras magallánicas con bosquetes de Nothofagus betuloides; $54^{\circ} 26^{\prime} 12^{\prime \prime} \mathrm{S}, 71^{\circ} 30^{\prime} 40^{\prime \prime} \mathrm{W}$; dentro del bosque y en rocas costeras, epífito en Berberis ilicifolia dentro del bosque costero; 21 Jan. 2011; J. Larrain 33321; NY • Comuna Cabo de Hornos, Parque Nacional Alberto de Agostini, Isla Grande de Tierra del Fuego, Ventisquero Alemania, NW-SE tending peninsula front

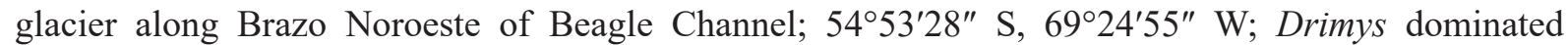
woodland with Nothofagus betuloides, on Nothofagus; 31 Jan. 2012; W.R. Buck 59027, p.p.; NY • Comuna Cabo de Hornos, Parque Nacional Alberto de Agostini, Isla Grande de Tierra del Fuego, W shore of Seno Ventisquero in small cove E of Mte. Novara; $54^{\circ} 45^{\prime} 17^{\prime \prime} \mathrm{S}, 70^{\circ} 18^{\prime} 49^{\prime \prime} \mathrm{W}$; small coastal Nothofagus-Drimys forest at base of cliff, on Nothofagus betuloides; 4 Feb. 2012; W.R. Buck 59306, p.p.; NY - Comuna Cabo de Hornos: Isla Hoste, S shore of Península Dumas, NW shore of Bahía Lagrese; 55 $05^{\prime} 40^{\prime \prime}$ S, 68 $37^{\prime} 19^{\prime \prime} \mathrm{W}$; wet Nothofagus-Drimys forest, on twigs of Berberis; 24 Jan. 2005; W.R. Buck 48079, p.p.; NY • Comuna Cabo de Hornos: Isla Hoste, S shore of Península Hardy, SW shore

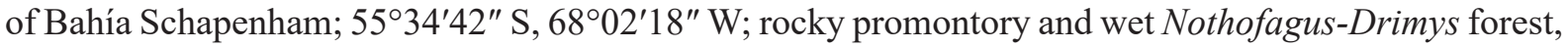
on twigs of Berberis; 25 Jan. 2005; W.R. Buck 48140; NY • Comuna Cabo de Hornos: Parque Nacional

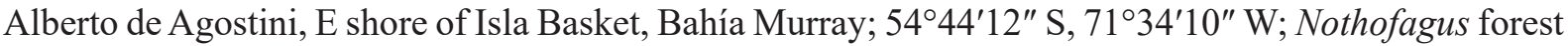
near shore, then Magellanic tundra leading to lakes, on coastal shrub; 1 Feb. 2011; W.R. Buck 57230; NY • ibid.; on Berberis; 1 Feb. 2011; W.R. Buck 57246, p.p.; NY • Comuna Cabo de Hornos: Parque Nacional Alberto de Agostini, Isla Grande de Tierra del Fuego, Península Rolando, at SE end of Seno Sargazos;

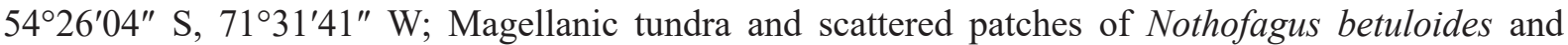
Drimys winteri beside rocky stream; 21 Jan. 2011; W.R. Buck 56851; NY • Comuna Cabo de Hornos: Parque Nacional Alberto de Agostini, Isla Grande de Tierra del Fuego, ENE arm of Seno Courtenay, S of glaciers; $54^{\circ} 34^{\prime} 39^{\prime \prime} \mathrm{S}, 71^{\circ} 10^{\prime} 42^{\prime \prime} \mathrm{W}$; wet Nothofagus antarctica forest with numerous small streams and waterfalls, on Berberis; 2 Feb. 2011; W.R. Buck 57300, p.p.; NY • Comuna Cabo de Hornos: Parque Nacional Alberto de Agostini, Isla Grande de Tierra del Fuego, $N$ end of north-central arill of Seno

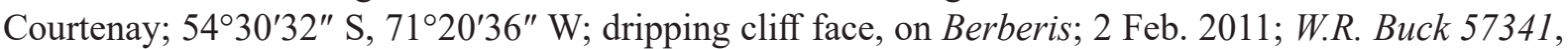
p.p.; NY • ibid.; W.R. Buck 57335; NY • Comuna Cabo de Hornos: Parque Nacional Alberto de Agostini, Isla Grande de Tierra del Fuego, Península Brecknock, ESE end of Seno Término; 54 $35^{\prime} 32^{\prime \prime}$ S, 71 ${ }^{\circ} 53^{\prime} 02^{\prime \prime}$ W; Nothofagus betuloides-Drimys forest at base of large massif, on Berberis; 6 Feb. 2011; W.R. Buck 57551; NY • Comuna Cabo de Hornos: Parque Nacional Alberto de Agostini, Isla Grande de

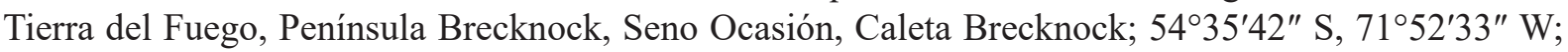
deep, steep-sided ravine leading to the sea, on Berberis; 6 Feb. 2011; W.R. Buck 57568; NY • Comuna Cabo de Hornos: Parque Nacional Alberto de Agostini, Isla Grande de Tierra del Fuego, Península Edwards, in larger of unnamed sounds between Punta Abrigo and Cabo Saliente, Puerto Langlois; $54^{\circ} 38^{\prime} 03^{\prime \prime} \mathrm{S}, 71^{\circ} 28^{\prime} 19^{\prime \prime} \mathrm{W}$; Magellanic tundra on rocky slope with small waterfalls, on coastal shrub; 3 Feb. 2011; W.R. Buck 57378; NY • ibid.; on Berberis; 3 Feb. 2011; W.R. Buck 57395, p.p.; NY • Comuna Cabo de Hornos: Parque Nacional Alberto de Agostini, Isla Grande de Tierra del Fuego, Península Rolando, at SE end of Seno Sargazos; 54 $26^{\prime} 04^{\prime \prime}$ S, $71^{\circ} 31^{\prime} 41^{\prime \prime}$ W; Magellanic tundra and scattered patches of Nothofagus betuloides and Drimys winteri beside rocky stream, on Berberis; 21 Jan. 2011; W.R. Buck 56840; NY • Comuna Cabo de Hornos: Parque Nacional Alberto de Agostini, Isla Grande de Tierra del Fuego, S of Canal Cockburn, SE end of Seno Bluff, Puerto Saco; 54 $26^{\prime} 31^{\prime \prime}$ S, $71^{\circ} 18^{\prime} 29^{\prime \prime}$ W; wet Nothofagus forest with multiple glacier-derived streams, on Berberis; 20 Jan. 2011; W.R. Buck 56684, p.p.; NY • ibid.; on Berberis twigs; 20 Jan. 2011; W.R. Buck 56725, p.p.; NY • ibid.; on Nothofagus twigs; 20 Jan. 2011; W.R. Buck 56763; NY • ibid.; on Nothofagus twigs; 20 Jan. 2011; W.R. Buck 56743; NY • ibid.; on Nothofagus twigs; 20 Jan. 2011; W.R. Buck 56717, p.p.; NY • Comuna Cabo de Hornos: Parque Nacional Alberto de Agostini, Isla Grande de Tierra del Fuego, S of Canal Cockburn, southernmost arm of Seno Bluff; 54⒉ $7^{\prime} 33^{\prime \prime}$ S, $71^{\circ} 23^{\prime} 11^{\prime \prime}$ W; Marsippospermum marsh with 
scattered trees of Drimys winteri, on Berberis; 20 Jan. 2011; W.R. Buck 56813; NY • Comuna Cabo de Hornos: Parque Nacional Alberto de Agostini, Isla Grande de Tierra del Fuego, W side of Seno Brujo,

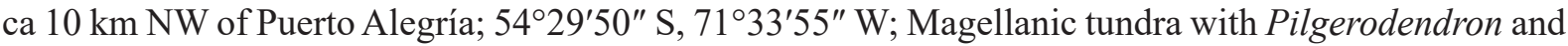
scattered patches of Nothofagus, on Berberis; 22 Jan. 2011; W.R. Buck 56893; NY - ibid.; on Pilgerodendron uviferum; 22 Jan. 2011; W.R. Buck 56882; NY • Comuna Cabo de Hornos: Parque Nacional Alberto de Agostini, N shore of Isla Macías on Canal Brecknock at Paso Aguirre; 54 $42^{\prime} 03^{\prime \prime}$ S, 71 ${ }^{\circ} 32^{\prime} 22^{\prime \prime}$ W; Magellanic tundra with rock outcrops, on Berberis; 3 Feb. 2011; W.R. Buck 57429; NY • ibid.; Magellanic tundra with rock outcrops, on Berberis; 3 Feb. 2011; W.R. Buck 57451; NY • Comuna Cabo de Hornos: Parque Nacional Alberto de Agostini, S shore of Isla Aguirre, S side of Seno Quo

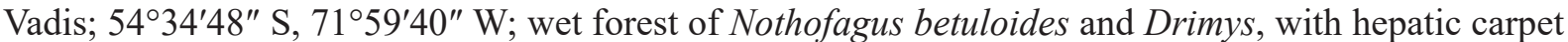
on forest floor, at base of cliff, on Berberis; 29 Jan. 2011; W.R. Buck 57115; NY • Comuna Cabo de Hornos: Parque Nacional Alberto de Agostini, SW shore of Isla Georgiana at widest part of channel opposite Isla Clementina; 54 $40^{\prime} 47^{\prime \prime} \mathrm{S}, 71^{\circ} 44^{\prime} 58^{\prime \prime} \mathrm{W}$; coastal Nothofagus betuloides-Drimys winteri forest with hepatic carpet, on Berberis; 31 Jan. 2011; W.R. Buck 57229; NY • Comuna Cabo de Hornos: Parque Nacional Alberto de Agostini, Tierra del Fuego, ENE arm of Seno Courtenay S of glaciers; $54^{\circ} 34^{\prime} 39^{\prime \prime} \mathrm{S}, 71^{\circ} 10^{\prime} 42^{\prime \prime} \mathrm{W}$; wet Nothofagus antarctica forest with numerous small streams and waterfalls, on Berberis; 2 Feb. 2011; W.R. Buck 57271, p.p.; NY • Comuna Cabo de Hornos: Parque Nacional Cabo de Hornos, Islas Wollaston, Isla Wollaston, W shore of Caleta Loberos at S end of Seno Alberto; $55^{\circ} 43^{\prime} 12^{\prime \prime} \mathrm{S}, 67^{\circ} 25^{\prime} 45^{\prime \prime} \mathrm{W}$; exposed grassy slope with rock exposures and Nothofagus forest in stream valleys, on branch of Nothofagus betuloides; 26 Jan. 2005; W.R. Buck 48170; NY • Comuna de Timaukel, Isla Grande de Tierra del Fuego, Parque Nacional Alberto de Agostini, ribera N del Seno Agostini,

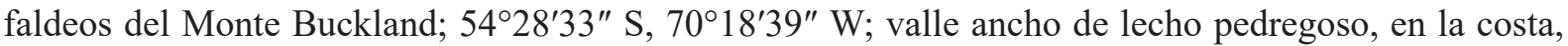
epífita en Gaultheria en el borde del bosque, en la costa; 25 Jan. 2011; J. Larraín 33502, p.p.; collected by J. Larraín and J. Shevock; NY • Isla Brecknock along southeastern shore near Cape Atracadero and across channel from Isla Macias; 544ㄴ ${ }^{\prime} 13.0^{\prime \prime} \mathrm{S}, 71^{\circ} 32^{\prime} 36.8^{\prime \prime} \mathrm{W}$; Nothofagus and Drimys stand along small stream, on branches of Berberis along streambank in sun; 3 Feb. 2011; J.R. Shevock 37470; NY • Isla Grande de Tierra del Fuego, eastern branch of Seno Courtenay in narrow fiord below glacier; $54^{\circ} 34^{\prime} 43.4^{\prime \prime} \mathrm{S}, 71^{\circ} 10^{\prime} 29.0^{\prime \prime} \mathrm{W}$; at edge of Nothofagus and Drimys forest in hummock area, on branches of Berberis in sun; 2 Feb. 2011; J.R. Shevock 37413, p.p.; NY • Isla Grande de Tierra del Fuego, end of Seno Chasco about Puerto Consuelo; 54 $32^{\prime} 19.5^{\prime \prime} \mathrm{S}, 71^{\circ} 31^{\prime} 49.3^{\prime \prime} \mathrm{W}$; pockets of Drimys and Nothofagus forest with grassland and granitic rocks on slopes, on Berberis stems in grassland in sun; 23 Jan 2011; J.R. Shevock 37125, p.p.; NY • Isla Grande de Tierra del Fuego, in unnamed sound directly east of Seno

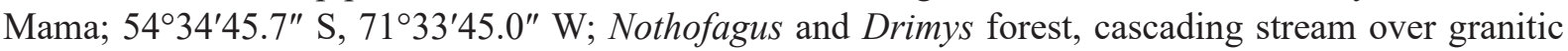
bedrock, on Berberis branches in sun; 4 Feb. 2011; J.R. Shevock 37510, p.p.; collected by J.R. Shevock and M. von Konrat; NY • Isla Grande de Tierra del Fuego, north end of north-central arm of Seno Courtenay; 54 $30^{\prime} 27.0^{\prime \prime} \mathrm{S}, 71^{\circ} 20^{\prime} 30.0^{\prime \prime} \mathrm{W}$; Magellanic tundra with granitic outcrops along rivulet, on branches of Berberis along rivulet in grassland in sun; 2 Feb. 2011; J.R. Shevock 37432, p.p.; NY • Isla Grande de Tierra del Fuego. Peninsula Rolando at southeast end of Seno Sargazos; 54 $26^{\prime} 11.3^{\prime \prime}$ S, $71^{\circ} 31^{\prime} 40.0^{\prime \prime} \mathrm{W}$; Marsippospermum grassland with scattered Drimys and Nothofagus, stems of Berberis above stream in sun; 21 Jan. 2011; J.R. Shevock 37066; NY • Isla Grande de Tierra del Fuego, Seno Brujo just north of Puerto Alegria, east-facing slopes with cascading streams originating from glaciers over granitic rock; 54 $30^{\prime} 00.0^{\prime \prime} \mathrm{S}, 71^{\circ} 33^{\prime} 55.0^{\prime \prime} \mathrm{W}$; Marsippospermum grassland with scattered Drimys and Nothofagus, on branches of hardwood shrubs along streambank in sun; 22 Jan. 2011; J.R. Shevock 37104, p.p.; NY • Isla Grande de Tierra del Fuego, South of Canal Cockburn, southeast end of Seno Bluff at Puerto Saco; $54^{\circ} 26^{\prime} 24.5^{\prime \prime} \mathrm{S}, 71^{\circ} 18^{\prime} 53.5^{\prime \prime} \mathrm{W}$; Nothofagus betuloides forest with ericaceous shrubs over granitic rock below glacier, on Berberis branches in sun; 20 Jan. 2011; J.R. Shevock 37014, p.p.; NY - Isla Grande de Tierra del Fuego, south of Canal Cockburn, southernmost arm of Seno Bluff; $54^{\circ} 27^{\prime} 31.0^{\prime \prime} \mathrm{S}, 71^{\circ} 23^{\prime} 14.3^{\prime \prime} \mathrm{W}$; forest of Drimys winteri and Marsippospermum grassland with ericaceous shrubs, on Pilgerodendron; 20 Jan. 2011; J.R. Shevock 37030, p.p.; NY • ibid.; on Berberis branches in sun; 20 Jan. 2011; J.R. Shevock 37031; NY • northeastem side of Isla London in an unnamed large bay 
just west of Islote Muela; $54^{\circ} 40^{\prime} 20.0^{\prime \prime} \mathrm{S}, 71^{\circ} 56^{\prime} 44.5^{\prime \prime} \mathrm{W}$; grassland at edge of Nothofagus and Drimys stand with streamlet in sun, on Berberis branches; 30 Jan. 2011; J.R. Shevock 37268; NY • Comuna Cabo de Hornos, Parque Nacional Alberto de Agostini, Isla Grande de Tierra del Fuego, S of Canal

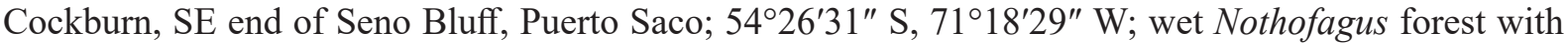
multiple glacier-derived streams, twig; 20 Jan. 2011; W.R. Buck 56774; NY • Comuna Cabo de Hornos, Parque Nacional Alberto de Agostini; SE coast of Isla Gordon in unnamed sound ca $10 \mathrm{~km} \mathrm{~W}$ of eastern

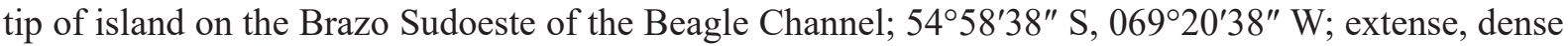
forest of Nothofagus betuloides along NNE exposed slopes, branches of Berberis ilicifolia; 19 Jan. 2012; R. Garilleti 2012-020; VAL-Briof - Comuna Cabo de Hornos, Parque Nacional Alberto de Agostini, SE coast of Isla Gordon in unnamed sound NW of Estero Penhoat across the SW arm of the Beagle Channel; 54 59'37" S, 69²8'31" W; open shrubby formation of Nothofagus betuloides, Berberis ilicifolia, Gaultheria mucronata and Chiliotrichum diffusum in the shore, surrounding a damped area, on Berberis ilicifolia; 20 Jan. 2012; R. Garilleti 2012-040Ab; VAL-Briof • Comuna Cabo de Hornos, Parque Nacional Alberto de Agostini, south-central coast of Isla Gordon, Caleta Caracoles, NW of Estero

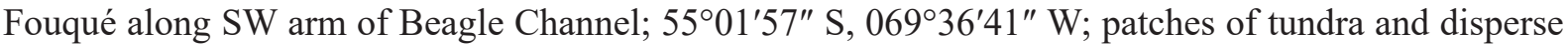
small areas of shrubby Nothofagus betuloides, horizontal trunk of Nothofagus betuloides; 20 Jan. 2012;

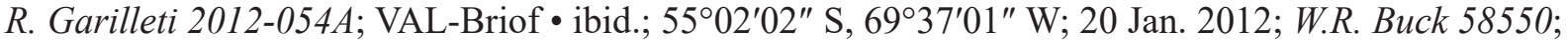
NY - Comuna de Cabo de Hornos, Parque Nacional Alberto de Agostini, north-central coast of Isla Hoste, ca $5 \mathrm{~km} \mathrm{~W}$ of the eastern tip of Isla Gordon along Brazo Sudoeste of Beagle Channel in unnamed

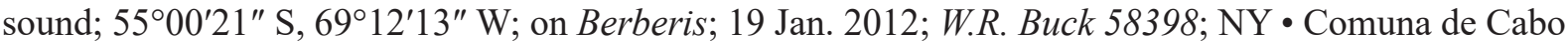
de Hornos, Parque Nacional Alberto de Agostini, N shore of Isla Hoste, SE end of Península Cloué, E side of Estero Fouque opposite Punta blanco near river draining small lake; 55 $09^{\prime} 48^{\prime \prime} \mathrm{S}, 69^{\circ} 31^{\prime} 01^{\prime \prime} \mathrm{W}$; on Nothofagus betuloides; 21 Jan. 2012; W.R. Buck 58636; NY • Comuna de Cabo de Hornos, Parque Nacional Alberto de Agostini, Isla Hoste, NW shore of Península Rous at E end of unnamed sound sharing its mouth with that of Estero Webb, terminating in rivers draining glacial lakes; $55^{\circ} 17^{\prime} 58^{\prime \prime} \mathrm{S}$, 69³3'24" W; on Berberis; 23 Jan. 2012; W.R. Buck 58734; NY • ibid.; on Berberis; 23 Jan. 2012; W.R. Buck58746; NY.

\section{Ulota macrocalycina Mitt.}

CHILE - Región Aysén del General Carlos Ibáñez del Campo • Provincia Capitán Prat: de Cochrane

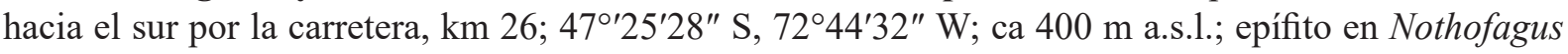
pumilio; 15 Jan. 2007; J. Larraín 26401A; collected by J. Larraín and R. Vargas; VAL-Briof • cruzando pasarela Río Ñadis; $47^{\circ} 29^{\prime} 49^{\prime \prime}$ S, $72^{\circ} 56^{\prime} 51^{\prime \prime}$ W; ca 70 m a.s.1.; epífito en Nothofagus dombeyi; 19 Jan. 2007; J. Larraín 26796B; collected by J. Larraín and R. Vargas; VAL-Briof. - Región de Magallanes y de la Antártica Chilena • Provincia de Magallanes: west of city of Punta Arenas, Brunswick Peninsula; $53^{\circ} 09^{\prime} 43.2^{\prime \prime} \mathrm{S}, 71^{\circ} 01^{\prime} 21.4^{\prime \prime} \mathrm{W} ; 320 \mathrm{~m}$ a.s.1.; on Nothofagus trunk roadbank in filtered light; $18 \mathrm{Jan}$. 2011 ; J.R. Shevock 36981; collected by J.R. Shevock and B. Shaw; NY • Comuna Cabo de Hornos, Isla Navarino, Parque Etnobotánico Omora; 54 56'40" S, 67³9'12" W; 30 m a.s.1.; sobre madera muerta; 10 Jan. 2012; R. Garilleti 2012-00X1; VAL-Briof • ibid.; bosque alterado de Nothofagus pumilio y Drimys winteri, sobre Berberis buxifolia; R. Garilleti 2012-00X2; VAL-Briof. • ibid.; sobre Nothofagus pumilio; 11 Jan. 2012; R. Garilleti 2012-00X3; VAL-Briof. 